\title{
Aplikasi Algoritma Branch and Bound Untuk Optimasi Jalur Pemadam Kebakaran Kota Yogyakarta
}

\author{
Sri Margiyani dan Noor Saif Muhammad Mussafi \\ Program Studi Matematika, Fakultas Sains dan Teknologi, UIN Sunan Kalijaga, JI. Marsda Adisucipto \\ No. 1 Yogyakarta, Indonesia \\ Korespondensi; Noor Saif Muhammad Mussafi, Email: om_norsa@yahoo.com
}

\begin{abstract}
Abstrak
Kasus kebakaran di Indonesia, khususnya Kota Yogyakarta dari tahun ke tahun masih menunjukkan angka yang tinggi. Hal ini mengakibatkan kerugian yang cukup tinggi bagi korban kebakaran. Untuk meminimalisasi terjadinya korban jiwa dan kerugian secara material saat terjadi kebakaran, maka pihak pemadam kebakaran mengupayakan melalui rute terpendek untuk sampai di lokasi kebakaran. Tujuan dari penelitian ini adalah pencarian rute terpendek jalur pemadam kebakaran dari kantor pemadam sampai ke lokasi kebakaran. Permasalahan pencarian rute terpendek jalur pemadam kebakaran secara abstrak dapat digambarkan dengan suatu graf yang merupakan masalah optimasi dalam pencarian rute terpendek (Shortest Path Problem). Pemecahan permasalahan tersebut adalah dengan merepresentasikan peta pemadam kebakaran ke dalam bentuk graf berbobot dan berarah, selanjutnya permasalahan diselesaikan menggunakan Algoritma Branch and Bound. Perhitungan dilakukan secara manual dengan jarak (dalam meter) sebagai bobot perhitungan. Berdasarkan perhitungan menggunakan Algoritma Branch and Bound untuk optimasi jalur pemadam kebakaran Kota Yogyakarta untuk wilayah Kecamatan Umbulharjo menghasilkan solusi rute: Kantor pemadam kebakaran - Jln. Ipda Tut Harsono - Jln. Kusumanegara - Jln. Glagahsari - Kantor Kecamatan Umbulharjo) dengan total jarak 5305 meter atau 5,035 km.
\end{abstract}

Kata Kunci: Algoritma Branch and Bound; Pencarian Rute Terpendek (Shortest Path Problem); Optimasi rute

\begin{abstract}
Cases of fire in Indonesia, especially the city of Yogyakarta from year to year still shows a high figure. This resulted in considerable losses for fire victims. To minimize the occurrence of casualties and material losses in the event of fire, the firefighters seek through the shortest route to reach the location of the fire. The purpose of this research is to search the shortest route of fire extinguisher line from fire station to fire location. The problem of finding the shortest route of the fire tract can be abstracted with a graph which is the optimization problem in the shortest path problem. Solving the problem is to represent the fire extinguisher map into the form of weighted and directed graph, then the problem solved using Branch and Bound Algorithm. Calculations are done manually by distance (in meters) as the calculation weights. Based on calculations using Branch and Bound Algorithm for optimizing fire trails Yogyakarta City for the District Umbulharjo produce route solutions: Firemen - Jln. Ipda Tut Harsono - Jln. Kusumanegara - Jln. Glagahsari - Umbulharjo District Office) with a total distance of 5305 meters or 5.035 km.
\end{abstract}

Keywords: Branch and Bound Algorithm; Shortest Path Quest (Shortest Path Problem); Route optimization

\section{Pendahuluan}

Peristiwa kebakaran merupakan bencana yang tidak bisa diprediksi sebelumnya. Peristiwa ini antara lain disebabkan oleh hubungan arus pendek listrik, puntung rokok yang dibuang di sembarang tempat, ledakan tabung gas LPG, dan lain-lain. Peristiwa kebakaran dapat menyebabkan kerugian yang cukup tinggi bagi korbannya. Sehingga dalam penanganannya harus tepat dan cepat.

Ketika kebakaran terjadi, pihak yang pertamakali dihubungi tentulah Dinas Pemadam Kebakaran. Untuk itu mobil pemadam kebakaran harus memilih jalur terpendek dari kantor pemadam kebakaran ke lokasi terjadinya kebakaran. Kota Yogyakarta mempunyai luas wilayah $32,50 \mathrm{~km}^{2}$. Walaupun wilayahnya tidak terlalu luas, namun memiliki tata ruang dan administrasi yang lengkap. Sehingga 
dalam penulisan ini wilayah yang akan dipilih adalah Kota Yogyakarta. Pencarian rute terpendek ini, dapat diselesaikan antara lain dengan Algoritma Branch and Bound. Algoritma Branch and Bound (B\&B) adalah suatu algoritma umum untuk pencarian solusi optimal dari berbagai masalah optimasi, khususnya optimasi diskrit dan kombinatorial. B\&B secara sistematis mengabaikan sekumpulan kandidat solusi yang tidak potensial menuju solusi optimal dengan menggunakan estimasi batas atas dan batas bawah (upper and lower estimated bounds) dari kuantitas yang dioptimasi. Metode ini pertama kali diusulkan oleh A. H. Land dan A. G. Doig pada tahun 1960 untuk linear programming.

\section{Landasan Teori}

Algoritma Branch and Bound merupakan algoritma yang membagi permasalahan menjadi sub masalah lebih kecil yang mengarah ke solusi dengan pencabangan (branching) dan melakukan pembatasan (bounding) untuk mencapai solusi optimal. Pencabangan (branching) yaitu proses membentuk permasalahan ke dalam bentuk struktur pohon pencarian (search tree). Proses Pencabangan dilakukan untuk membangun semua cabang pohon yang menuju solusi, sedangkan proses pembatasan dilakukan dengan menghitung estimasi nilai (cost) simpul dengan memperhatikan batas. Branch and Bound pertama kali dikemukakan oleh A. H. Land dan A. G. Doig pada tahun 1960 (Suyanto, 2010:81).

Secara umum algoritma Branch and Bound dalam melakukan pencarian solusi menggunakan teknik Least Cost Search atau pencarian nilai terkecil, teknik ini akan menghitung nilai (cost) setiap simpul. Simpul yang memiliki nilai paling kecil dikatakan memiliki kemungkinan paling besar menuju solusi.

Setiap simpul aktif (current node) mempunyai sebuah nilai yang menyatakan nilai batas (bound). Sebuah simpul aktif merupakan simpul yang mempunyai nilai batas terkecil (karena teknik pencarian solusi Least Cost Search) (Eko Budi P., 2008: 244).

Misal $c(i)$ adalah nilai estimasi lintasan minimum dari simpul $i$ ke simpul tujuan, jadi $c(i)$ menyatakan batas (bound) nilai pencarian solusi dari simpul $i$. Sehingga dapat dirumuskan fungsi heuristic untuk menghitung nilai estimasi sebagai berikut:

$$
c(i)=f(i)+f(i)
$$

Dengan:

$c(i)$ : Nilai untuk simpul $i$

$f(i)$ : Nilai lintasan dari simpul akar ke simpul $i$

$g(i)$ : Nilai untuk mencapai simpul tujuan dari simpul $i$

Untuk permasalahan yang lebih komplek, sistem digambarkan dengan matriks $A$ ukuran $n x n$. Untuk dipilih simpul mana yang akan dieksplorasi. Simpul yang dieksplorasi adalah simpul dengan nilai batas terkecil. Nilai batas didapatkan dari reduksi baris dan kolom matriks $A$ yang merepresentasikan graf. Reduksi dilakukan dengan mengurangi nilai $c_{i j}$ pada baris atau kolom dengan nilai $c_{i j}$ terkecil pada baris atau kolom tersebut, sedemikian sehingga didapatkan matriks tereduksi $A(t)$ dengan sebuah nilai nol pada setiap baris dan kolom. Menurut Suyanto (2010), sebuah matriks dikatakan tereduksi jika setiap kolom dan barisnya mengandung minimal satu nilai nol dan semua elemen lainnya non-negatif. Selanjutnya total nilai pereduksi menjadi nilai batas simpul akar. Untuk setiap simpul anak yang dibangkitkan dengan mengunjungi $A(i, j)$, dilakukan reduksi matriks $A(t)$ untuk mendapatkan matriks tereduksi $A(j$, simpul awal) diubah menjadi $\infty$.

Berdasarkan persamaan fungsi heuristik untuk menghitung nilai estimasi yang telah dijelaskan sebelumnya, maka nilai batas simpul anak dihitung dengan rumus:

$$
\hat{c}(S)=\hat{c}(R)+A(i, j)+r
$$

Dimana:

$\hat{c}(S) \quad$ : nilai perjalanan minimum yang melalui simpul $S$, dimana $S$ adalah anak dari simpul $R$. 
$\hat{c}(R)$ : Nilai perjalanan minimum yang melalui simpul $R$, dimana $R$ adalah simpul akar.

$A(i, j)$ : bobot sisi $(i, j)$ pada matriks tereduksi.

$r \quad$ : jumlah semua pereduksi pada proses reduksi matriks untuk simpul $S$.

Reduksi matriks simpul anak didasarkan pada matriks simpul induknya. Langkah ini dikerjakan berulang-ulang sampai semua simpul dikunjungi.

Langkah langkah untuk menjalankan algoritma Branch and Bound sebagai berikut:

1. Masukkan simpul akar ke dalam antrian $Q$. Jika simpul akar adalah simpul solusi (goal node), maka solusi telah ditemukan. Stop.

2. Jika $Q$ kosong, tidak ada solusi. Stop.

3. (i). Jika $\mathrm{Q}$ tidak kosong, pilih dari antrian $Q$ simpul $i$ yang mempunyai $c(i)$ paling kecil. (ii). Jika terdapat beberapa simpul $i$ yang memenuhi, pilih salah satu simpul sembarang.

4. (i). Jika simpul $i$ adalah simpul solusi, maka solusi ditemukan, stop. (ii). Jika simpul $i$ bukan simpul solusi, maka bangkitkan semua simpul anak-anaknya. (iii). Jika i tidak mempunyai anak, kembali ke langkah 2.

5. Untuk setiap anak $j$ dari $i$, hitung $c(i)$ dan masukkan semua anak-anak tersebut ke dalam $Q$.

6. Kembali ke langkah 2.

\section{Pembahasan}

Kecamatan Umbulharjo notabene merupakan wilayah terluas di Kotamadya Yogyakarta diasumsikan dapat mewakili kondisi kecamatan lainnya. Gambar 1 menunjukkan peta kecamatan Umbulharjo yang diperoleh dari aplikasi google earth.

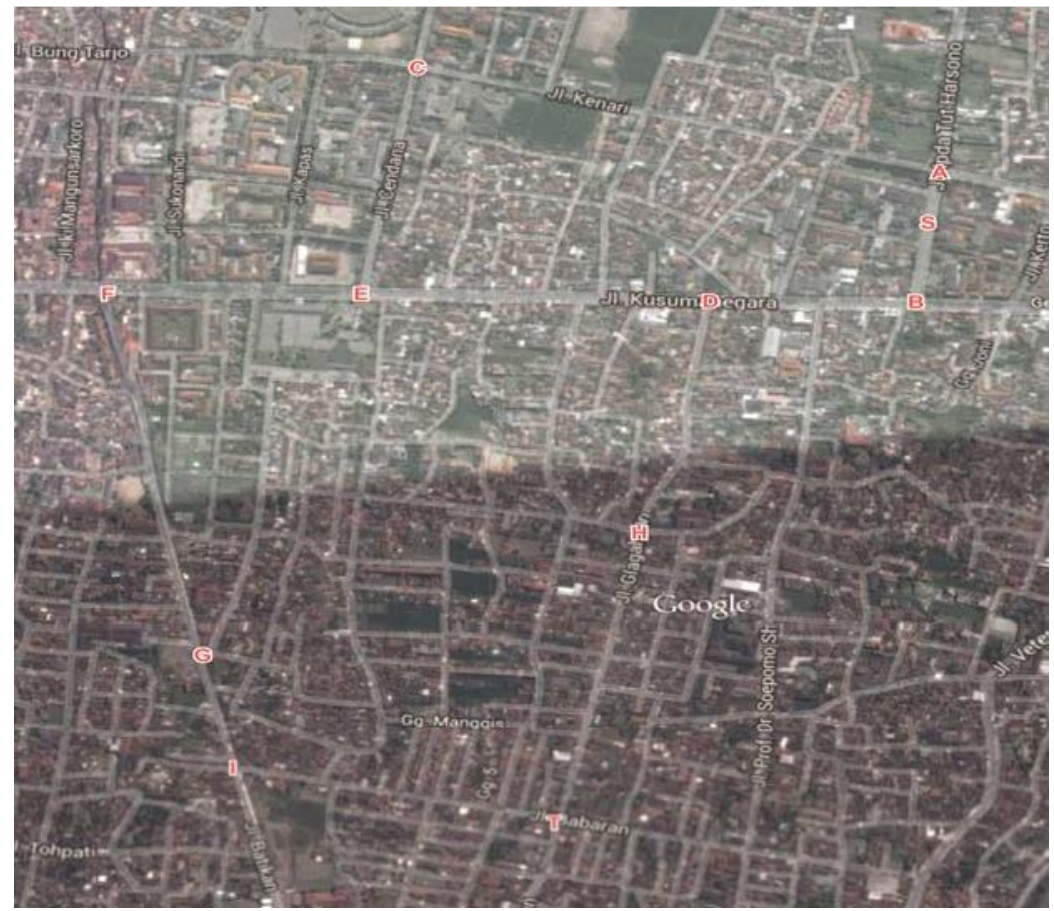

Gambar 1 Peta Kecamatan Umbulharjo.

Peta di atas dapat direpresentasikan dalam graf berbobot berikut ini: 


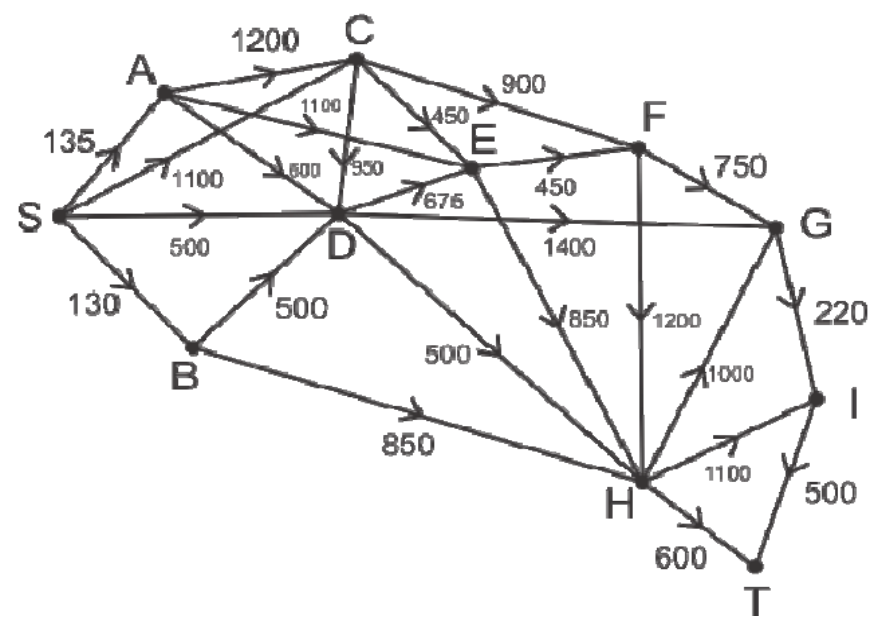

Gambar 2 Graf Berbobot Kecamatan Umbulharjo.

Selanjutnya langkah-langkah penerapan Algoritma Branch and Bound Untuk Optimasi Jalur Pemadam Kebakaran Kota Yogyakarta khususnya wilayah kecamatan Umbulharjo dapat disajikan sebagai berikut: 1. Representasikan graf kedalam bentuk matriks

2. Reduksi setiap baris dan setiap kolom, sehingga setiap baris dan setiap kolom mengandung minimal satu nilai 0 . Sehingga didapat matriks tereduksi:

\begin{tabular}{c|ccccccccccc}
\hline & $\mathrm{S}$ & $\mathrm{A}$ & $\mathrm{B}$ & $\mathrm{C}$ & $\mathrm{D}$ & $\mathrm{E}$ & $\mathrm{F}$ & $\mathrm{G}$ & $\mathrm{H}$ & $\mathrm{I}$ & $\mathrm{T}$ \\
\hline $\mathrm{S}$ & $\infty$ & 0 & 0 & 370 & 370 & $\infty$ & $\infty$ & $\infty$ & $\infty$ & $\infty$ & $\infty$ \\
$\mathrm{A}$ & $\infty$ & $\infty$ & $\infty$ & 0 & 0 & 500 & $\infty$ & $\infty$ & $\infty$ & $\infty$ & $\infty$ \\
$\mathrm{B}$ & $\infty$ & $\infty$ & $\infty$ & $\infty$ & 0 & $\infty$ & $\infty$ & $\infty$ & 350 & $\infty$ & $\infty$ \\
$\mathrm{C}$ & $\infty$ & $\infty$ & $\infty$ & $\infty$ & 500 & 0 & 450 & $\infty$ & $\infty$ & $\infty$ & $\infty$ \\
$\mathrm{D}$ & $\infty$ & $\infty$ & $\infty$ & $\infty$ & $\infty$ & 175 & $\infty$ & 900 & 0 & $\infty$ & $\infty$ \\
$\mathrm{E}$ & $\infty$ & $\infty$ & $\infty$ & $\infty$ & $\infty$ & $\infty$ & 0 & $\infty$ & 400 & $\infty$ & $\infty$ \\
$\mathrm{F}$ & $\infty$ & $\infty$ & $\infty$ & $\infty$ & $\infty$ & $\infty$ & $\infty$ & 0 & 450 & $\infty$ & $\infty$ \\
$\mathrm{G}$ & $\infty$ & $\infty$ & $\infty$ & $\infty$ & $\infty$ & $\infty$ & $\infty$ & $\infty$ & $\infty$ & 0 & $\infty$ \\
$\mathrm{H}$ & $\infty$ & $\infty$ & $\infty$ & $\infty$ & $\infty$ & $\infty$ & $\infty$ & 400 & $\infty$ & 500 & 0 \\
$\mathrm{I}$ & $\infty$ & $\infty$ & $\infty$ & $\infty$ & $\infty$ & $\infty$ & $\infty$ & $\infty$ & $\infty$ & $\infty$ & 0 \\
$\mathrm{~T}$ & $\infty$ & $\infty$ & $\infty$ & $\infty$ & $\infty$ & $\infty$ & $\infty$ & $\infty$ & $\infty$ & $\infty$ & $\infty$ \\
\hline
\end{tabular}

Dimisalkan matriks tereduksi diatas $=$ matriks $\mathbf{T}$

1. Simpul kedua yaitu A, lintasan S-A

a. Ubah baris $S$ kolom $A$ pada Matiks $T$ menjadi $\infty$.

b. Ubah $\mathrm{T}(\mathrm{A}, \mathrm{S})$ menjadi $\infty$ (elemen baris $\mathrm{A}$ kolom $\mathrm{S}$ pada matriks $\mathrm{T}$ ).

c. Reduksi baris dan kolom dengan $c_{i j}$ terkecil, karena tidak ada proses reduksi maka $r=0$

d. $\hat{c}(2)=\hat{c}($ root $)+A(S, A)+r=5305+0+0=5305$

2. Simpul ketiga yaitu $B$, lintasan $S-B$

a. Ubah baris $S$ kolom $A$ pada Matiks $T$ menjadi $\infty$.

b. Ubah $\mathrm{T}(\mathrm{A}, \mathrm{S})$ menjadi $\infty$ (elemen baris $\mathrm{A}$ kolom $\mathrm{S}$ pada matriks $\mathrm{T}$ ).

c. Reduksi baris dan kolom dengan $c_{i j}$ terkecil, karena tidak ada proses reduksi maka $r=0$

d. $\hat{c}(3)=\hat{c}($ root $)+A(S, B)+r=5305+0+0=5305$

3. Simpul keempat yaitu $C$, lintasan $S-C$

a. Ubah baris $\mathrm{S}$ kolom $\mathrm{C}$ pada Matiks $\mathrm{T}$ menjadi $\infty$.

b. Ubah $\mathrm{T}(\mathrm{C}, \mathrm{S})$ menjadi $\infty$ (elemen baris $\mathrm{C}$ kolom $\mathrm{S}$ pada matriks $\mathrm{T}$ ).

c. Reduksi baris dan kolom dengan $c_{i j}$ terkecil, karena tidak ada proses reduksi maka $r=0$

d. $\hat{c}(4)=\hat{c}($ root $)+A(S, C)+r=5305+370+0=5675$ 
4. Simpul kelima yaitu $D$, lintasan S-D

a. Ubah baris $S$ kolom $D$ pada Matiks $T$ menjadi $\infty$.

b. Ubah $T(D, S)$ menjadi $\infty$ (elemen baris $D$ kolom $S$ pada matriks $T$ ).

c. Reduksi baris dan kolom dengan $c_{i j}$ terkecil. Baris B dikurangi 350 sehingga $r=350$

d. $\hat{c}(5)=\hat{c}($ root $)+A(S, D)+r=5305+370+350=6025$

5. Simpul keenam yaitu $C$, lintasan $S-A-C$

a. Ubah semua elemen pada baris $S$, baris $A$ dan kolom $A$, kolom $C$ pada Matiks $T$ menjadi $\infty$.

b. Ubah $\mathrm{T}(\mathrm{C}, \mathrm{A})$ menjadi $\infty$ (elemen baris $\mathrm{C}$ kolom $\mathrm{A}$ pada matriks $\mathrm{T}$ ).

c. Reduksi baris dan kolom dengan $c_{i j}$ terkecil, karena tidak ada proses reduksi maka $r=0$

d. $\hat{c}(6)=\hat{c}($ root $)+A(A, C)+r=5305+0+0=5305$

6. Simpul ketujuh yaitu $E$, lintasan $S-A-E$

a. Ubah semua elemen pada baris $S$, baris $A$ dan kolom A, kolom E pada Matiks T menjadi $\infty$.

b. Ubah $\mathrm{T}(\mathrm{E}, \mathrm{A})$ menjadi $\infty$ (elemen baris $\mathrm{E}$ kolom $\mathrm{A}$ pada matriks $\mathrm{T}$ ).

c. Reduksi baris dan kolom dengan $c_{i j}$ terkecil. Baris $C$ dikurangi 450, sehingga $r=450$

d. $\hat{c}(7)=\hat{c}($ root $)+A(A, E)+r=5305+500+450=6255$

7. Simpul kedelapan yaitu $D$, lintasan S-A-D

a. Ubah semua elemen pada baris $S$, baris $A$ dan kolom $A$, kolom D pada Matiks $T$ menjadi $\infty$.

b. Ubah $T(D, A)$ menjadi $\infty$ (elemen baris $D$ kolom $A$ pada matriks $T$ ).

c. Reduksi baris dan kolom dengan $c_{i j}$ terkecil. Baris B dikurangi 350, sehingga $r=350$

d. $\hat{c}(8)=\hat{c}($ root $)+A(A, D)+r=5305+0+350=5655$

8. Simpul kesembilan yaitu D, lintasan S-B-D

a. Ubah semua elemen pada baris $S$, baris B dan kolom B, kolom D pada Matiks T menjadi $\infty$.

b. Ubah $\mathrm{T}(\mathrm{D}, \mathrm{B})$ menjadi $\infty$ (elemen baris $\mathrm{D}$ kolom $\mathrm{B}$ pada matriks $\mathrm{T}$ ).

c. Reduksi baris dan kolom dengan $c_{i j}$ terkecil, karena tidak ada proses reduksi maka $r=0$

d. $\hat{c}(9)=\hat{c}($ root $)+A(B, D)+r=5305+0+0=5305$

9. Simpul kesepuluh yaitu $\mathrm{H}$, lintasan $\mathrm{S}-\mathrm{B}-\mathrm{H}$

a. Ubah semua elemen pada baris $S$, baris B dan kolom B, kolom $H$ pada Matiks $T$ menjadi $\infty$.

b. Ubah $\mathbf{T}(\mathrm{H}, \mathrm{B})$ menjadi $\infty$ (elemen baris $\mathrm{H}$ kolom $\mathrm{B}$ pada matriks $\mathrm{T}$ ).

c. Reduksi baris dan kolom dengan $c_{i j}$ terkecil. Baris $\mathrm{D}$ dikurangi 175 , sehingga $r=175$

d. $\hat{c}(10)=\hat{c}($ root $)+A(B, H)+r=5305+350+175=5830$

10. Simpul kesebelas yaitu $D$, lintasan S-A-C-D

a. Ubah semua elemen pada baris $S$, baris $A$ dan baris $C$ serta kolom $A$, kolom $C$ dan kolom D pada Matiks T menjadi $\infty$.

b. Ubah $T(D, C)$ menjadi $\infty$ (elemen baris $D$ kolom $C$ pada matriks $T$ ).

c. Reduksi baris dan kolom dengan $c_{i j}$ terkecil. Baris B dikurangi 350 dan kolom E dikurangi 175, sehingga $r=525$

d. $\hat{c}(11)=\hat{c}($ root $)+A(C, D)+r=5305+500+525=6330$

11. Simpul keduabelas yaitu $E$, lintasan $S-A-C-E$

a. Ubah semua elemen pada baris $S$, baris $A$ dan baris $C$ kolom $A$, kolom $C$ dan kolom $D$ pada Matiks T menjadi $\infty$.

b. Ubah $T(D, C)$ menjadi $\infty$ (elemen baris $D$ kolom $C$ pada matriks $T$ ).

c. Reduksi baris dan kolom dengan $c_{i j}$ terkecil, karena tidak ada proses reduksi maka $r=0$

d. $\hat{c}(12)=\hat{c}($ root $)+A(C, E)+r=5305+0+0=5305$

12. Simpul ketigabelas yatu $F$, lintasan $\mathrm{S}-\mathrm{A}-\mathrm{C}-\mathrm{F}$

a. Ubah semua elemen pada baris $S$, baris $A$ dan baris $C$ kolom $A$, kolom $C$ dan kolom $D$ pada Matiks T menjadi $\infty$.

b. Ubah $\mathrm{T}(\mathrm{D}, \mathrm{C})$ menjadi $\infty$ (elemen baris $\mathrm{D}$ kolom $\mathrm{C}$ pada matriks $\mathrm{T}$ ).

c. Reduksi baris dan kolom dengan $c_{i j}$ terkecil. Kolom E dikurangi 175 , sehingga $r=175$

d. $\hat{c}(13)=\hat{c}($ root $)+A(C, F)+r=5305+450+175=5930$ 
13. Simpul keempatbelas yaitu $E$, lintasan $S-B-D-E$

a. Ubah semua elemen pada baris $S$, baris A dan baris $C$ serta kolom A, kolom $C$ dan kolom $D$ pada Matiks T menjadi $\infty$.

b. Ubah $\mathrm{T}(\mathrm{D}, \mathrm{C})$ menjadi $\infty$ (elemen baris $\mathrm{D}$ kolom $\mathrm{C}$ pada matriks $\mathrm{T}$ ).

c. Reduksi baris dan kolom dengan $c_{i j}$ terkecil. Baris C dikurangi 450 dan kolom H dikurangi 400, sehingga $r=850$

d. $\hat{c}(14)=\hat{c}($ root $)+A(D, E)+r=5305+175+850=6330$

14. Simpul kelimabelas yaitu $G$, lintasan S-B-D-G

a. Ubah semua elemen pada baris $\mathrm{S}$, baris $\mathrm{A}$ dan baris $\mathrm{C}$ serta kolom $\mathrm{A}$, kolom $\mathrm{C}$ dan kolom $\mathrm{D}$ pada Matiks T menjadi $\infty$.

b. Ubah $\mathrm{T}(\mathrm{D}, \mathrm{C})$ menjadi $\infty$ (elemen baris $\mathrm{D}$ kolom $\mathrm{C}$ pada matriks $\mathrm{T}$ ).

c. Reduksi baris dan kolom dengan $c_{i j}$ terkecil. Baris F dikurangi 450 dan kolom G dikurangi 400, sehingga $r=850$

d. $\hat{c}(15)=\hat{c}($ root $)+A(D, G)+r=5305+900+850=7055$

15. Simpul keenambelas yaitu $H$, lintasan S-B-D-H

a. Ubah semua elemen pada baris $S$, baris B dan baris $D$ serta kolom B, kolom D dan kolom $H$ pada Matiks T menjadi $\infty$.

b. Ubah $T(D, H)$ menjadi $\infty$ (elemen baris $D$ kolom $H$ pada matriks $T$ ).

c. Reduksi baris dan kolom dengan $c_{i j}$ terkecil, karena tidak ada proses reduksi maka $r=0$

d. $\hat{c}(16)=\hat{c}($ root $)+A(D, H)+r=5305+0+0=5305$

16. Simpul ketujuhbelas yaitu $F$, lintasan S-A-C-E-F

a. Ubah semua elemen pada baris $S$, baris $A$, baris $C$ dan baris $E$ serta kolom A, kolom C, kolom E dan kolom $F$ pada Matiks $T$ menjadi $\infty$.

b. Ubah $\mathrm{T}(\mathrm{E}, \mathrm{F})$ menjadi $\infty$ (elemen baris $\mathrm{E}$ kolom $\mathrm{F}$ pada matriks $\mathrm{T}$ ).

c. Reduksi baris dan kolom dengan $c_{i j}$ terkecil, karena tidak ada proses reduksi maka $r=0$

d. $\hat{c}(17)=\hat{c}($ root $)+A(E, F)+r=5305+0+0=5305$

17. Simpul kedelapanbelas yaitu $\mathrm{H}$, lintasan S-A-C-E-H

a. Ubah semua elemen pada baris $S$, baris $A$, baris $C$ dan baris $E$ serta kolom A, kolom $C$, kolom $\mathrm{E}$ dan kolom $\mathrm{F}$ pada Matiks $\mathrm{T}$ menjadi $\infty$.

b. Ubah $\mathrm{T}(\mathrm{E}, \mathrm{F})$ menjadi $\infty$ (elemen baris $\mathrm{E}$ kolom $\mathrm{F}$ pada matriks $\mathrm{T}$ ).

c. Reduksi baris dan kolom dengan $c_{i j}$ terkecil. Baris D dikurangi 900, sehingga $r=900$

d. $\hat{c}(18)=\hat{c}($ root $)+A(E, H)+r=5305+400+900=6055$

18. Simpul kesembilanbelas yaitu I, lintasan S-B-D-H-I

a. Ubah semua elemen pada baris $S$, baris $B$, baris $D$ dan baris $H$ serta kolom $B$, kolom $D$, kolom $\mathrm{H}$ dan kolom I pada Matiks $\mathrm{T}$ menjadi $\infty$.

b. Ubah $\mathbf{T}(\mathrm{H}, \mathrm{I})$ menjadi $\infty$ (elemen baris $\mathrm{H}$ kolom I pada matriks $\mathrm{T}$ ).

c. Reduksi baris dan kolom dengan $c_{i j}$ terkecil, karena tidak ada proses reduksi maka $r=0$

d. $\hat{c}(19)=\hat{c}($ root $)+A(D, G)+r=5305+500+0=5805$

19. Simpul keduapuluh yaitu $G$, lintasan S-B-D-H-G

a. Ubah semua elemen pada baris $\mathrm{S}$, baris $\mathrm{B}$, baris $\mathrm{D}$ dan baris $\mathrm{H}$ serta kolom $\mathrm{B}$, kolom $\mathrm{D}$, kolom $\mathrm{H}$ dan kolom I pada Matiks $\mathrm{T}$ menjadi $\infty$.

b. Ubah $\mathbf{T}(\mathrm{H}, \mathrm{I})$ menjadi $\infty$ (elemen baris $\mathrm{H}$ kolom I pada matriks $\mathrm{T}$ ).

c. Reduksi baris dan kolom dengan $c_{i j}$ terkecil, karena tidak ada proses reduksi maka $r=0$

d. $\hat{c}(20)=\hat{c}($ root $)+A(H, G)+r=5305+400+0=5705$

20. Simpul keduapuluhsatu yiatu G, lintasan S-B-D-H-T

a. Ubah semua elemen pada baris $S$, baris $B$, baris $D$ dan baris $H$ serta kolom B, kolom D, kolom $\mathrm{H}$ dan kolom $\mathrm{T}$ pada Matiks $\mathrm{T}$ menjadi $\infty$.

b. Ubah $\mathbf{T}(\mathrm{H}, \mathrm{T})$ menjadi $\infty$ (elemen baris $\mathrm{H}$ kolom $\mathrm{T}$ pada matriks $\mathrm{T}$ ).

c. Reduksi baris dan kolom dengan $c_{i j}$ terkecil, karena tidak ada proses reduksi maka $r=0$

d. $\hat{c}(21)=\hat{c}($ root $)+A(H, T)+r=5305+0+0=5305$ 


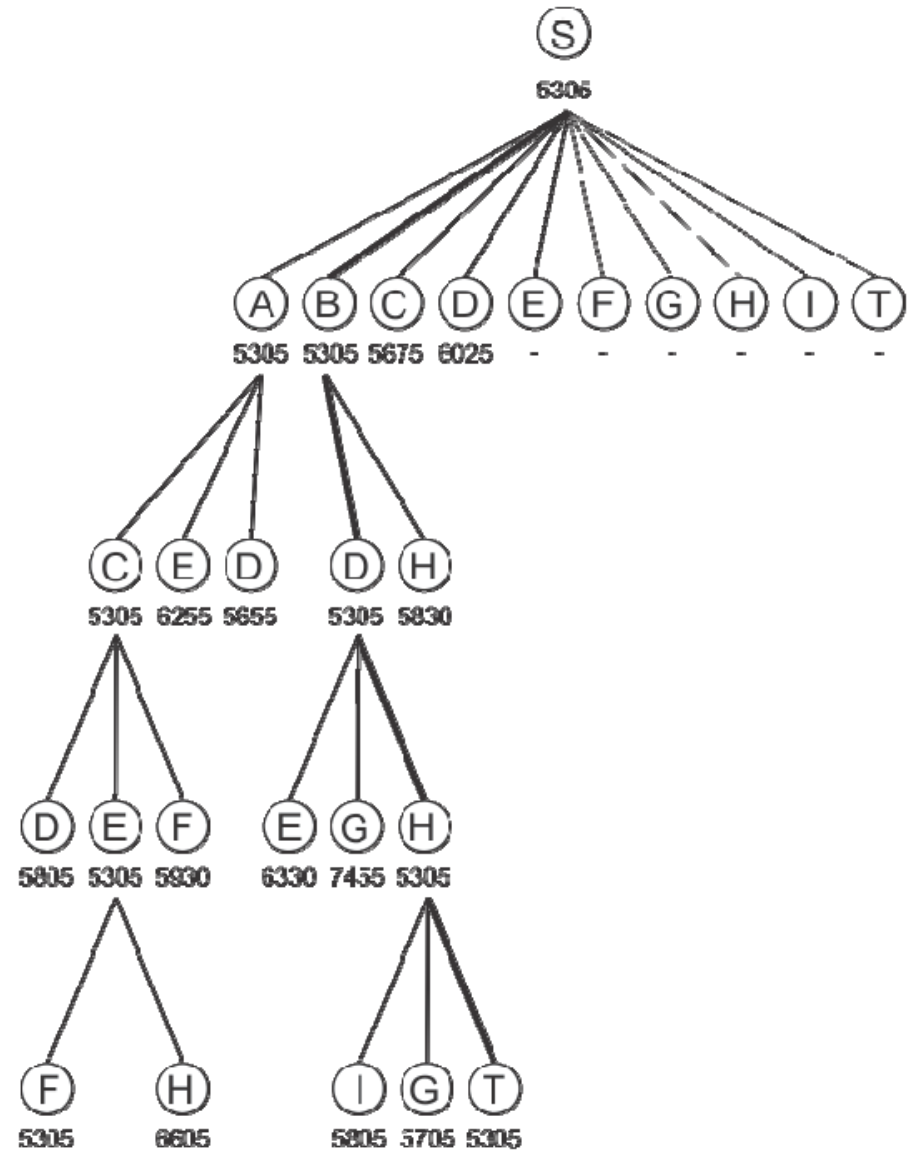

Gambar 3 Branch and Bound Kecamatan Umbulharjo.

Jadi jalur terpendek menurut Algoritma Branch and Bound dari kantor Pemadam Kebakaran Kota Yogyakarta sampai Kecamatan Umbulharjo menurut branch and bound gambar 3 adalah $5305 \mathrm{~m}=$ $5,305 \mathrm{~km}$.

\section{Kesimpulan dan Saran}

Penerapan Algoritma Branch and Bound untuk optimasi jalur pemadam kebakaran Kota Yogyakarta dilakukan dengan cara merepresentasikan peta rute pemadam kebakaran dalam bentuk graf berbobot dan berarah. Sehingga dihasilkan solusi rute pemadam kebakaran dengan jarak minimal. Berdasarkan perhitungan dengan menggunakan Algoritma Branch and Bound diperoleh solusi rute pemadam kebakaran, Kantor pemadam kebakaran sampai Kecamatan Umbulharjo Rute S-B-D-H-T (Kantor pemadam kebakaran Jln. Ipda Tut Harsono-JIn. Kusumanegara-JIn. Glagahsari-Kantor Kecamatan Umbulharjo) dengan total jarak 5305 meter atau 5,035 km. Berdasarkan penelitian yang telah dilakukan, ada beberapa saran untuk peneliti selanjutnya:

1. Penelitian ini hanya menggunakan Teknik FIFO B\&B, diharapkan penelitian selanjutnya bisa menggunakan teknik lain seperti Teknik LIFO B\&B dan Teknik LC- Search B\&B.

2. Bobot yang digunakan dalam penelitian ini berupa jarak (dalam meter) dan mengabaikan kepadatan lalu lintas serta kondisi jalan. Diharapkan penelitian selanjutnya dapat menggunakan kepadatan lalu lintas atau kondisi jalan sebagai bobot dalam graf rute pemadam kebakaran.

3. Perhitungan yang dilakukan dalam penelitian ini masih secara manual. Diharapkan penelitian selanjutnya dapat melakukan perhitungan dengan pemrograman komputer. 


\section{Referensi}

[1] Abdusakir dkk. (2009). Teori Graf. Malang: UIN-Malang Press.

[2] Aldous, Joan M. and Wilson, Robin J. (2000). Graph and Applications: An Introductory Approach. Great Britain: Springer.

[3] Anton, Howard (2000). Dasar-dasar Aljabar .Edisi 7.Jakarta: Interaksara

[4] Bondy, J.A. dan Murty, U.S.R. (1976). Graph Theory with Applications. London: The Macmillan Press Itd.

[5] Budi Purwanto, Eko (2008). Perancangan dan Analisis Algoritma. Yogyakarta: Graha Ilmu.

[6] Levitin, Anany (2010). Pengantar Desain dan Analisis Algoritma. Edisi ke 2. Diterjemahkan oleh: Efrizal Zaida. Jakarta: Salemba Infotek.

[7] Lipschuzt, Seymour and Lipson, Marc (2008). Schaums Outlines Matematika Diskret. Edisi ke 3. Diterjemahkan oleh Thombi Layukallo. Jakarta: Erlangga.

[8] Purwanto, Eko Budi (2008). Perancangan dan Analisis Algoritma. Yogyakarta: Graha Ilmu.

[9] Rossen, Kenneth H. (2012). Discrete Mathematics And Its Applications. 7th ed. New York: The MCGraw- Hill Companies, Inc.

[10] Saptono, F. dan Taufiq Hidayat. (2007). Perancangan Algoritma Genetika Untuk Menentukan Jalur Terpendek. Yogyakarta: SNATI

[11] Shofi A., Muhammad (2013).Implementasi Algoritma Branch and Bound untuk Optimasi Rute Pengangkutan Sampah Kota Yogyakarta. Skripsi.Yogyakrta: Program Studi Matematika Fakultas Sains dan Teknologi UIN Sunan Kalijaga.

[12] Suryahadi (1990). Pengantar Teori dan Algoritma Graph. Jakarta: Penerbit Gunadarma.

[13] Suyanto (2010). Algoritma Optimasi (Deterministik atau Probabilistik). Yogyakarta: Graha Ilmu.

[14] Wibisono, Samuel (2008). Matematika Diskrit. Yogyakarta: Graha Ilmu. 